\begin{tabular}{|c|c|c|}
\hline \multirow{3}{*}{$\begin{array}{r}\text { Case Reports in } \\
\text { Gastroenterology }\end{array}$} & \multirow{2}{*}{\multicolumn{2}{|c|}{ Case Rep Gastroenterol 2014;8:129-133 }} \\
\hline & & \\
\hline & $\begin{array}{l}\text { DOI: 10.1159/000362442 } \\
\text { Publisnea oninne: April J, } 2014\end{array}$ & $\begin{array}{l}\text { ○ } 2014 \text { S. Karger AG, Basel } \\
\text { 1662-0631/14/0081-0129 } \$ 39.50 / 0 \\
\text { www.karger.com/crg }\end{array}$ \\
\hline & \multicolumn{2}{|c|}{$\begin{array}{l}\text { This is an Open Access article licensed under the terms of the Creative Commons } \\
\text { Attribution-NonCommercial } 3.0 \text { Unported license (CC BY-NC) (www.karger.com/OA } \\
\text { license), applicable to the online version of the article only. Distribution permitted for non } \\
\text { commercial purposes only. }\end{array}$} \\
\hline
\end{tabular}

\title{
Acute Liver Injury in a Patient with Alcohol Dependence: A Case Resembling Autoimmune Hepatitis or Drug-Induced Liver Injury
}

\author{
Masahiro Hayashi Tatsuo Kanda Masato Nakamura \\ Tatsuo Miyamura Shin Yasui Shingo Nakamoto Shuang Wu \\ Makoto Arai Fumio Imazeki Osamu Yokosuka
}

Department of Gastroenterology and Nephrology, Chiba University Graduate School of Medicine, Chiba, Japan

\section{Key Words}

Acute liver injury · Alcohol dependence · Autoimmune hepatitis · Drug-induced liver injury

\begin{abstract}
Some patients with alcohol dependence may initially present with atypical laboratory and histological features resembling autoimmune hepatitis (AIH) or drug-induced liver injury (DILI). Even with liver biopsy, it may be difficult to diagnose certain patients with alcohol dependence. However, careful follow-up of our patient and consultations with the attending psychiatrist were successful in diagnosing alcohol dependence and its liver injury. The immune mechanisms of alcoholic liver diseases, AIH and DILI may be overlapping. Certain patients are suffering from AIH with flares on a background of alcohol abuse. Certain patients with alcohol abuse may have a past history of DILI. This might be consistent with the fact that alcohol dependence initially presents with atypical laboratory features of AIH or DILI. With careful observation, the clinician should remind himself that alcohol dependence is not always required for developing liver disease, since many patients with liver disease do not meet the criteria for alcohol dependence.

(c) 2014 S. Karger AG, Basel
\end{abstract}

Tatsuo Kanda, MD, PhD, Assoc. Prof

Department of Gastroenterology and Nephrology

Chiba University Graduate School of Medicine

1-8-1 Inohana, Chuo-ku, Chiba 260-8670 (Japan)

E-Mail kandat-cib@umin.ac.jp 
Hayashi et al.: Acute Liver Injury in a Patient with Alcohol Dependence: A Case Resembling Autoimmune Hepatitis or Drug-Induced Liver Injury

\section{Introduction}

Liver diseases other than autoimmune hepatitis (AIH) can present with laboratory features of AIH [1]. Alcoholic liver injury as well as drug-induced liver injury (DILI) occasionally resemble chronic hepatitis [2].

It has been reported that the activation of innate immune cells and the inflammatory cascade play a central role in the pathology of alcoholic liver disease [3]. Toll-like receptor 4 (TLR4) expressed on innate immune cells and hepatocytes could recognize the gut-derived endotoxin and the TLR4-downstream could be activated through the interferon regulatory factor 3 (IRF3) [3]. Drugs and/or their metabolites and host immunological factors are rarely involved in idiosyncratic DILI $[4,5]$ and trigger a T cell-mediated cytotoxicity or B cell antibody response $[5,6]$. These results suggest that the mechanisms of these liver diseases may be overlapping.

We report a woman with alcohol dependence who initially presented with atypical laboratory features resembling AIH or DILI. Even with liver biopsy, it is difficult to diagnose certain patients. Attention should be paid to the fact that alcoholic liver injury in some cases resembles AIH or DILI.

\section{Case Report}

A 50-year-old Japanese woman was referred to Chiba University Hospital in April 2012 because of jaundice and abnormal liver tests. She took several drugs for her depression and hypertension and drank alcohol ( $\sim 90 \mathrm{~g}$ daily). One year before admission, she had had a history of DILI by mianserin for her depression. Her height and body weight were $152 \mathrm{~cm}$ and $55 \mathrm{~kg}$, respectively. She did not have hepatic encephalopathy. Laboratory findings were as follows: white blood cell count 7,100/ $\mathrm{ll}$ (eosinophils $0.8 \%$ ), platelets $155,000 / \mu \mathrm{l}$, prothrombin time 18\% (INR 2.36), total protein $5.3 \mathrm{~g} / \mathrm{dl}$, total bilirubin $21.9 \mathrm{mg} / \mathrm{dl}$ (direct bilirubin $15.0 \mathrm{mg} / \mathrm{dl}$ ), alkaline phosphatase $313 \mathrm{IU} / \mathrm{l}$, aspartate aminotransferase (AST) $314 \mathrm{IU} / \mathrm{l}$, alanine aminotransferase (ALT) $112 \mathrm{IU} / \mathrm{l}$, and $\gamma$-glutamyl transpeptidase $190 \mathrm{IU} / \mathrm{l}$. Serum immunoglobulin G of 1,695 mg/dl and immunoglobulin $\mathrm{M}$ of $116 \mathrm{mg} / \mathrm{dl}$ were normal, but antinuclear antibody (ANA) was not positive $(\times 80)$. Virus serology was negative for hepatitis A, B, C and E viruses, cytomegalovirus and Epstein-Barr virus acute infection. Computed tomography and abdominal ultrasound findings showed a non-atrophic liver with slightly ascites. We suspected a diagnosis of DILI or AIH, although her AIH score was underscored [7, 8], and administered corticosteroids. She was given bed rest and peripheral parenteral nutrition.

After 2 weeks, AST (73 IU/l), ALT (136 IU/l), total bilirubin (3.4 mg/dl) and prothrombin time (92\%) were improved and liver biopsy was performed to diagnose her disease (fig. 1). Hepatic architecture was preserved without cirrhosis, and inflammation of the periportal area was obvious with centrilobular necrosis. There were mononuclear cells in the portal area, but marked plasma cell infiltration was not observed. This observation might have been affected by the corticosteroid therapies. We diagnosed her as acute exacerbation of chronic hepatitis of unknown etiology. After $\sim 1$ month, she was discharged (AST $22 \mathrm{IU} / \mathrm{l}$, ALT $56 \mathrm{IU} / \mathrm{l}$, total bilirubin $1.8 \mathrm{mg} / \mathrm{dl}$ and prothrombin time 98\%). Two months later, her liver test had suddenly deteriorated (AST 76 IU/l, ALT 249 IU/l and $\gamma$-glutamyl transpeptidase 1,262 IU/l). At the same time, we became aware of her alcohol consumption and she was diagnosed with alcohol dependence by a psychiatrist. 
Hayashi et al.: Acute Liver Injury in a Patient with Alcohol Dependence: A Case Resembling Autoimmune Hepatitis or Drug-Induced Liver Injury

\section{Discussion}

We present a patient whose liver biopsy findings did not reveal any influence of alcohol and whose level of $\gamma$-glutamyl transpeptidase at administration was much lower than that after 2 months. Unfortunately, we were not aware of her alcohol dependence while she was hospitalized. Our patient had a previous history of DILI, and liver biopsy showed chronic active hepatitis, but not cirrhosis [9]. Alcohol consumption is a common comorbid condition with other chronic liver diseases and may exacerbate liver injury in autoimmune liver diseases and chronic viral hepatitis [10]. This synergism can result in increased hepatic inflammation and accelerated rates of fibrosis, although the influence of alcohol consumption in this patient with acute liver injury is unclear. This could explain our patient having severe liver injury with coagulopathy.

Alcohol consumption has been proposed as a risk factor for DILI from medication, although there is still insufficient evidence to support this [11]. We speculate that alcohol consumption might have worsened the background chronic liver injury of undetermined etiology. There are several mechanisms by which alcohol consumption might explain the flare of hepatitis. There is a recent report that deletion of sirtuin 1, which is a nicotinamide adenine dinucleotide-dependent protein deacetylase that regulates hepatic lipid metabolism by modifying histones and transcription factors, promotes steatosis, inflammation and fibrosis in response to ethanol challenge [12]. In alcohol-induced liver disease, the MyD88independent but IRF3-mediated TLR4 signaling plays a role in alcohol-related liver inflammation and liver damage [3]. Gut-derived lipopolysaccharide, a ligand of TLR4, plays an important role in triggering and maintaining the activation of Kupffer cells in alcoholic hepatitis. Innate immune signaling might be important in hepatic cell death.

In the present case, the liver function tests, histology, female gender, positive ANA and the remarkable resolution of disease on administration of corticosteroids all strongly point to this being AIH (acute-on-chronic exacerbation) although her AIH score was underscored $[7,8]$. The liver test worsening 2 months later might have been an indicator of AIH. Liver histology of the present case was silent on the salient features of alcoholic hepatitis $[13,14]$ : steatosis, marked perivenular and pericellular fibrosis, ballooning degeneration with neutrophilic inflammation, and Mallory bodies in spite of the elevation of $\gamma$-glutamyl transpeptidase. Carbohydrate-deficient transferrin, one of biological markers of alcoholism, might be useful [15].

Usually AIH is diagnosed after excluding alcohol, hepatitis B and hepatitis $C$ virus as a cause of liver injury [7, 8]. Certain patients suffer from AIH with flares, on a background of alcohol abuse. This might be consistent with the fact that alcohol dependence initially presents with atypical laboratory features of AIH or DILI.

In conclusion, it is important to remind oneself that alcohol dependence is not required for developing liver disease, since many patients with liver disease do not meet the criteria for alcohol dependence. In some cases, it is difficult to diagnose alcoholic liver injury even by liver biopsy. In any case, our patient should have been advised to stop drinking alcohol when discharged. However, careful follow-up of the patient and consultation with a psychiatrist were useful in diagnosing alcohol dependence and related liver injury. 


\begin{tabular}{l|l}
\hline \multicolumn{2}{l}{ Case Rep Gastroenterol 2014;8:129-133 } \\
\hline DOI: $10.1159 / 000362442$ & $\begin{array}{l}\text { C 2014 S. Karger AG, Basel } \\
\text { www.karger.com/crg }\end{array}$ \\
\hline
\end{tabular}

Hayashi et al.: Acute Liver Injury in a Patient with Alcohol Dependence: A Case Resembling Autoimmune Hepatitis or Drug-Induced Liver Injury

\section{References}

1 Efe C, Ozaslan E, Purnak T, Ozseker B, Kav T, Bayraktar Y: Liver biopsy is a superior diagnostic method in some patients showing the typical laboratory features of autoimmune hepatitis. Clin Res Hepatol Gastroenterol 2012;36:185-188.

-2 Kanda T, Yokosuka O, Tada M, Kurihara T, Yoshida S, Suzuki Y, Nagao K, Saisho H: N-nitroso-fenfluramine hepatotoxicity resembling chronic hepatitis. J Gastroenterol Hepatol 2003;18:999-1000.

-3 Szabo G, Petrasek J, Bala S: Innate immunity and alcoholic liver disease. Dig Dis 2012;30(suppl 1):55-60.

4 Amacher DE: The primary role of hepatic metabolism in idiosyncratic drug-induced liver injury. Expert Opin Drug Metab Toxicol 2012;8:335-347.

5 Kancherla D, Gajendran M, Vallabhaneni P, Vipperla K: Metronidazole induced liver injury: a rare immune mediated drug reaction. Case Rep Gastrointest Med 2013;2013:568193.

6 Tujios S, Fontana RJ: Mechanisms of drug-induced liver injury: from bedside to bench. Nat Rev Gastroenterol Hepatol 2011;8:202-211.

7 Alvarez F, Berg PA, Bianchi FB, Bianchi L, Burroughs AK, Cancado EL, Chapman RW, Cooksley WG, Czaja AJ, Desmet VJ, Donaldson PT, Eddleston AL, Fainboim L, Heathcote J, Homberg JC, Hoofnagle JH, Kakumu S, Krawitt EL, Mackay IR, MacSween RN, Maddrey WC, Manns MP, McFarlane IG, Meyer zum Büschenfelde KH, Zeniya M: International Autoimmune Hepatitis Group Report: review of criteria for diagnosis of autoimmune hepatitis. J Hepatol 1999;31:929-938.

-8 Hennes EM, Zeniya M, Czaja AJ, Parés A, Dalekos GN, Krawitt EL, Bittencourt PL, Porta G, Boberg KM, Hofer H, Bianchi FB, Shibata M, Schramm C, Eisenmann de Torres B, Galle PR, McFarlane I, Dienes HP, Lohse AW; International Autoimmune Hepatitis Group: Simplified criteria for the diagnosis of autoimmune hepatitis. Hepatology 2008;48:169-176.

-9 Moreau R, Jalan R, Gines P, Pavesi M, Angeli P, Cordoba J, Durand F, Gustot T, Saliba F, Domenicali M, Gerbes A, Wendon J, Alessandria C, Laleman W, Zeuzem S, Trebicka J, Bernardi M, Arroyo V; CANONIC Study Investigators of the EASL-CLIF Consortium: Acute-on-chronic liver failure is a distinct syndrome that develops in patients with acute decompensation of cirrhosis. Gastroenterology 2013;144:1426-1437. Lee M, Kowdley KV: Alcohol's effect on other chronic liver diseases. Clin Liver Dis 2012;16:827-837. Chalasani N, Björnsson E: Risk factors for idiosyncratic drug-induced liver injury. Gastroenterology 2010;138:2246-2259.

12 Yin H, Hu M, Liang X, Ajmo JM, Li X, Bataller R, Odena G, Stevens SM Jr, You M: Deletion of SIRT1 from hepatocytes in mice disrupts lipin-1 signaling and aggravates alcoholic fatty liver. Gastroenterology 2014;146:801-811.

Lefkowitch JH: Morphology of alcoholic liver disease. Clin Liver Dis 2005;9:37-53.

Crawford JM: Histologic findings in alcoholic liver disease. Clin Liver Dis 2012;16:699-716.

Maruyama K, Yokoyama A, Matsui T, Mizukami T, Mizukami Y, Sogawa K, Yokosuka O, Nomura F,

Yokoyama T: Higher serum free glycerol levels in a group of alcoholics than in controls. Alcohol Clin Exp Res 2012;36:1820-1826. 
Hayashi et al.: Acute Liver Injury in a Patient with Alcohol Dependence: A Case Resembling Autoimmune Hepatitis or Drug-Induced Liver Injury
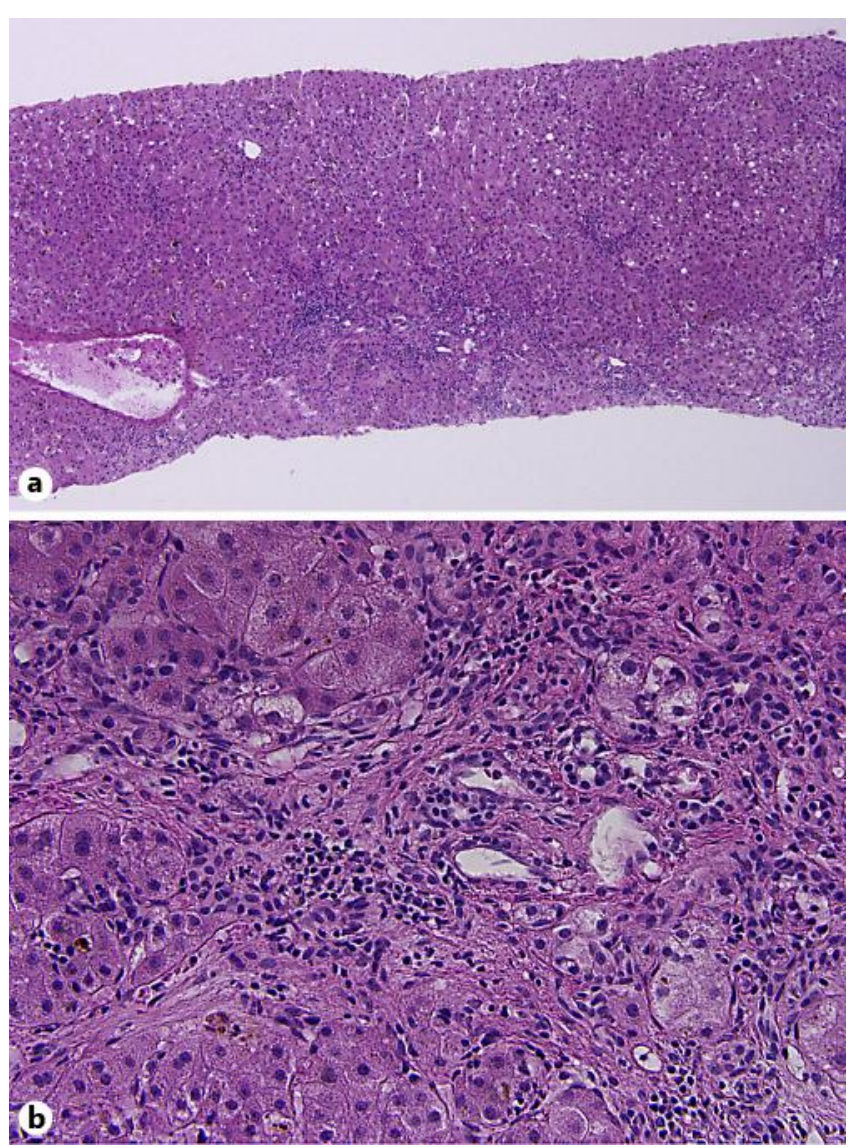

Fig. 1. Liver biopsy showed preserved hepatic architecture without cirrhosis (hematoxylin and eosin, $\times 40$ ) (a) and marked inflammation in the periportal area with fibrosis (hematoxylin and eosin, $\times 100$ ) (b). 